\title{
The Role Of Marketing In Making The Transition From State Of The Art Technology To Advanced Technology Products
}

Stacy M. P. Schmidt, (Email: stacy_schmidt3@firstclass1.csubak.edu), California State University, Bakersfield David L. Ralph, (Email: david.ralph@ @epperdine.edu), Pepperdine University

Bruce D. Buskirk, Pepperdine University

\begin{abstract}
This paper reviews the Technological Life Cycle with emphasis place on the shift between the State of the Art stage of Technology and the Advanced Stage of Technology. Difficulties are discussed and recommendations are made to overcome technological stage shift difficulties.
\end{abstract}

\section{THE ROLE OF MARKETING IN MAKING THE TRANSITION FROM STATE OF THE ART TECHNOLOGY TO ADVANCED TECHNOLOGY PRODUCTS}

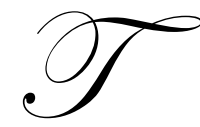

his paper explores the problems high tech firms face when their core technical expertise ages from "State of the Art" B2B products to "Advance" consumer products/services technology, and makes recommendations on how these pitfalls can be avoided. The framework for this analysis will be the six stages of technology as described in the "Technology Life Cycle" as developed by Buskirk (1986)

\section{DESCRIPTION OF THE TECHNOLOGICAL LIFE CYCLE}

Industrial markets function differently from consumer markets. While consumer marketing uses the product life cycle (PLC) as the cornerstone for understanding product/market behavior, the use of PLC in industrial and high tech markets has received little attention. A central explanation for this difference in the applicability of PLC between consumer and industrial markets is the consumer markets' identification of technological progress and fashion.

Fashion, or change for the sake of change, has value to the consumer. Yet, industry often fails to appreciate the drive for novelty that consumers seek. Consumers often consume goods in a conspicuous manner. Goods consumed in such a manner are often felt to reflect upon the self-concept of the consumer. The more conspicuous the consumption, the more likely that the goods consumed will require constant fashion updating. Such conspicuously consumed goods become extensions of one's personality. For some consumer goods, fashion is the essence of the product. Hence, fashion can be the driving factor of the consumer product life cycle.

It would be difficult to quantify the effects of fashion changes on a consumer product versus functional improvements. Doubtless, the factors that determine the shape of the sales curve over time for assembly line robots are quite different from the factors that determine the pattern of the PLC for designer jeans. On the other hand it would be unreasonable to expect that the robots' sales "curve" would have a stable, linear growth driven only by rational, economic market processes. While both consumer and industrial may reflect cyclic sales, the forces that drive those cycles are different. 
It is, therefore, the contention of this paper that the PLC in not well suited to analysis of industrial markets. The PLC combines three basic trends in the marketplace: fashion, technology, and benefits sought by the market place. While consumer marketing could benefit by the separation of these three factors, that is not the purpose of this paper. Conversely, all three factors are involved, to some extent, in industrial markets. However, in industrial markets there is a tendency for customers to place substantially less value on fashion in the products that they purchase. Further, both consumers and industrial users are slow to seek different basic benefits than they have enjoyed from their adopted products in the past unless that product's capability to provide benefits has changed dramatically. The source of change is not in the value of the benefit as much as in the ability of the product to provide that benefit ... in other words, the change is in the technology underlying the product. As such, when focusing on the industrial marketplace, technology can be isolated as a critical factor effecting fluctuations in sales over time in a given product category.

\section{SIX STAGES OF THE TECHNOLOGY LIFE CYCLE}

The evolution of a technology through a marketplace, or a Technological Life Cycle (TLC) can be divided into six basic phases.

1. Cutting Edge

2. State of the Art (SOTA)

3. Advanced

4. Mainstream

5. Mature

6. Decline

\section{Cutting Edge}

Cutting edge (or sometimes called leading edge) technological firms, while principally engaging in Pure Research, seldom develop their technology without a specific application in mind. However, that application is likely to be limited and abstract. The measure of success for that technology is whether the marketplace can find additional applications.

Cutting Edge firms seldom have the expertise to fully commercialize their technological developments. Further, the cutting edge firm tends to produce their technology in the same fashion in which they discovered it... that is a batch process. Cutting edge firms are not experts in production.

\section{State Of The Art}

State of the Art firms are high tech firms that are able to commercialized cutting edge technologies, that is they are able to translate the sophisticated attributes developed in research into benefits sought by the industrial marketplace. More importantly, State of the Art firms have expertise in production. The State of the Art firm is able to develop, or acquire technologies, and bring that technology to mass production.

State of the Art firms often make substantial profits. They are often able to keep the price of their technology at the level of when the technology was produced in batch process, however they are able to reduce their costs via mass production techniques.

The large margins maintained by State of the Art firms eventually attract competition. New entrants into the industry will often trigger rapid price decreases. The entrenched State of the Art firm will most often have the lowest cost of production, and as such have a strong advantage over their competitors. Interestingly however, the rapidly decreasing cost of the technology open up a plethora of consumer applications for the technology. The rapidly decreasing prices for the technology meet an increasingly elastic demand curve. technology.

The lower prices, competition, and consumer applications are the earmarks of the shift into the advanced stage of 


\section{Advanced Stage Of Technology}

The advanced stage of technology is characterized by rapidly growing consumer application, targeted to innovators. The technology tends to be consumer unfriendly, and consumers are satisfied if they can just get the technology to "work". When Henry Ford stated that he made cars in any color desired "so long as it was black", he was describing the automobile in its advanced stage of technology.

This paper addresses the difficulties facing management in the shift from the State of the Art stage of technology to the Advanced stage. Firms, dominated by technological competition, whose customers are other sophisticated businesses, find themselves ill prepared to market consumer goods. Figure 1 below illustrates the principle that as a technology ages, it requires increasing expenditures on marketing, and decreasing expenditures on engineering, or other technological resources.

While the allocation of Engineering and marketing is shown as a straight line over time, that is only due the representation of the Technological Life cycle as being steady and equal, when in fact at times the Technological Life Cycle can move very quickly, as is the case between State of the Art and Advance, or slowly as it often does during the mature stage . Hence, as the Technological Life Cycle matures quickly, the shift from Engineering expenditures to Marketing expenditures also accelerates proportionally.

Figure 1

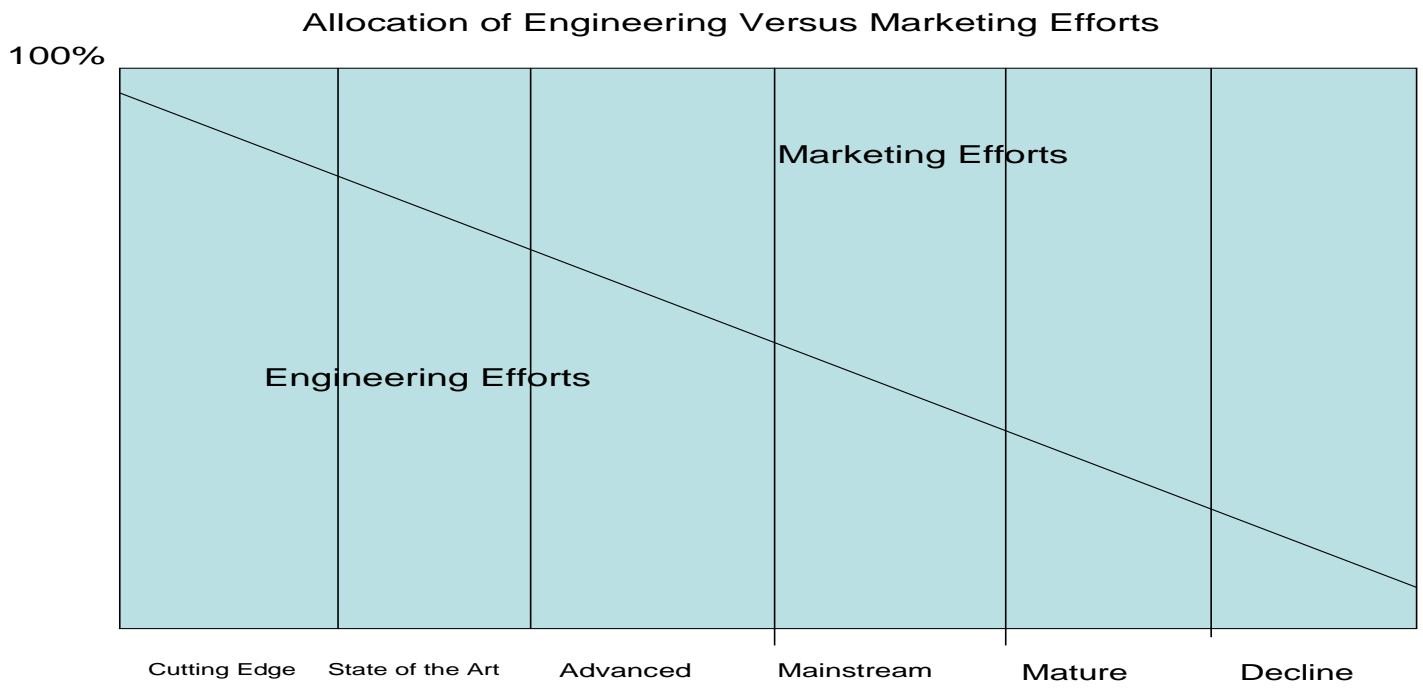

\section{Mainstream}

This stage of technology is characterized by a shift from product feature competition, to segmentation competition. The shift is usually marked by the product coming in "colors". Product features become standardized, and other means of differentiation become rampant.

\section{Mature}

Mature stage of technology begins when a competitive technology enters the marketplace. 


\section{Decline}

The technology is in the marketplace only because of past "sunk cost" capital expenditures. When the machines that produce the good wear out, they are not replaced, and the technology dies. However, until that time, the good is produced and can economically compete in niche markets. Not all technologies die. Most older technologies find permanent niches.

\section{TECHNOLOGICAL TRANSITIONS ARE DIFFICULT ON MANAGEMENT}

Knowing the Stage of the Technological life Cycle a firm in which a firm is working is of strategic importance. Management must be ready to shift resources as a technology ages. High-Technology firms tend to be in the Cutting Edge or State of the Art phases of their technology. These firms by their very nature are most often product driven. When firms make a shift with their technology to the advanced stage, the firm must also shift from being product oriented to being market oriented. This is often very difficult for the firm to accept.

Buskirk and Popper (1994) expand Ansoff's growth matrix to include a firms ability to grow toward high tech options as well as the possibility of integrating advanced technologies into their present product line. Hence, firms must examine growth in three directions, old and new markets, products, and technologies.

\begin{tabular}{|c|l|l|l|}
\hline & $\begin{array}{l}\text { Product } \\
\text { Present }\end{array}$ & $\begin{array}{l}\text { Product } \\
\text { Future }\end{array}$ & $\begin{array}{l}\text { Product } \\
\text { New Technology }\end{array}$ \\
\hline Present & $\begin{array}{l}\text { Market } \\
\text { Penetration }\end{array}$ & $\begin{array}{l}\text { Product } \\
\text { Development }\end{array}$ & $\begin{array}{l}\text { Technological } \\
\text { Product } \\
\text { Substitution }\end{array}$ \\
\hline Market & $\begin{array}{l}\text { Market } \\
\text { Development }\end{array}$ & Diversification & $\begin{array}{l}\text { High } \\
\text { Technology }\end{array}$ \\
\hline
\end{tabular}

In most situations the most difficult transition is between the State of the Art stage and Advanced. Firms may choose to remain "high-tech" and specialize in B2B high-tech solutions. However, this must be a conscious decision to remain in the State of the Art stage. In practice this quite often means an investment in the technical personnel required in new emerging areas, as well as the reduction in force of technical staff who are unable to re-tool to the newer technology. The firm does not have an easy choice or path regardless of their chosen direction.

At Apple, Stephen Jobs one of the two computer engineers who founded the company and was largely responsible for its early growth and success was replaced, as president, by John Scully an experienced Consumer Marketing Manager from Pepsico. This management change reflected the different needs Apple faced as it entered an advanced stage of the TLC. In a similar move Atari brought in James J. Morgan a senior consumer marketing executive from Philip Morris in response to a more aggressively competitive and dynamic marketplace than Atari management was accustomed. Neither of these managerial shifts proceeded smoothly. In both cases the firms' founders and entrepreneurial leaders left as they failed to meet the changing needs of a marketing orientation.

\section{EXPERIENCE CURVE EFFECTS IN THE ADVANCED STAGE OF THE TLC}

Firms which develop a technology tend to attempt to maintain a high price for that technology, while gaining reduced costs of production due to experience curve effects (reflecting both economies of scale and scope as well as learning effects. This can result in substantial gross margins which are, in fact, usually necessary to recoup the research costs of developing the technology. These funds are also needed to fund the research and development of future technologies. 
New entrants into the market are often not aware of how low the marginal and variable costs of production are, or can be, for the established developer of the technology. Make no mistake, the firm that leads on the experience curve has a natural advantage and it is particularly difficult to catch up to the leader on that curve (unless a competitor can move into the product's market share leadership position). Thus, even with "head-on" competition, the firm with the lowest marginal cost can flood the market with a price above their cost, but below the cost of their competitors. This allows the market leader to earn profits while eliminating competition. This fact is what makes market segmentation (or niche strategies) critical to firms who cannot compete on price. While marketing can make a substantial difference, the industrial marketplace can be cruel to the best of sales organizations if their products are perceived to be inferior, and/or overpriced. This is especially true during the earlier stages of the TLC.

All of these factors (managerial transition, market over estimation, and experience curve pricing) lead to a market "shake-out". Market growth, at some point in time, does not live up to expectation, or new entrants into the field manage to erode market shares among market leaders. Either case can trigger the start of the "shake-out". When one firm lowers price, the others must follow or risk losing market share. Technically trained management is often too quick to turn to price reductions to solve their marketing problems (perhaps reflecting an over reliance, by technical managers of the economically based notion that all competition is one the basis of price). Not surprisingly, as prices rapidly fall, only those firms with the lowest marginal cost survive. The industry, as a whole, often loses money trying to outlive the price war, while driving their competitors out of business first, and gaining large market share for long-run profitability. In the trenches of High Tech Warfare when price wars break out the manager who attempts to cut the competitor's through (by slashing prices) is often the one who bleeds to death.

Participation in such price wars have several pitfalls. The most obvious of these is running out of money before the competition does (e.g. bleeding to death). However, there are other critical strategic considerations. First, will product quality be lowered to support the price cuts required to compete. If so, the customer may label the firm's products as junk damaging the firm's ability to "trade-up" after the price war.

The price war may also train customers to be price sensitive, and expect prices to fall over time rather than rise (as is currently the case in the personal computer marketplace). These factors can lock a firm into the undesirable position where price is the only means of competing in the market place. The alternative, of course, is to segment the market and pursue a niche strategy to survive the shakeout and prosper.

One common transition problem is the mind set of management. All previous problems faced by the firm were solved via technology, research, and engineering solutions. When faced with consumer marketing problems, the knee jerk reaction of management is to develop a better product, in technological terms, than the competition. Good customer service is rarely thought to be a path to competitive success, despite market research explicitly revealing the markets desire for better customer service.

The technological oriented mangers of the State of the Art firm quite often just refuse to release their hold on the reins of the firm. The result is a tumultuous shift from engineering to marketing driven. See Figure 2.

Figure 2 demonstrates a struggle for power between Engineering and Marketing. In this example the firm has a management that is too Engineering oriented for the first half of the Advanced stage, then too Marketing oriented during the second half of the Advanced stage. Domination of either orientation is to the detriment of the firm. 
Figure 2: The Problem Curve - When Engineering Hangs On Too Long

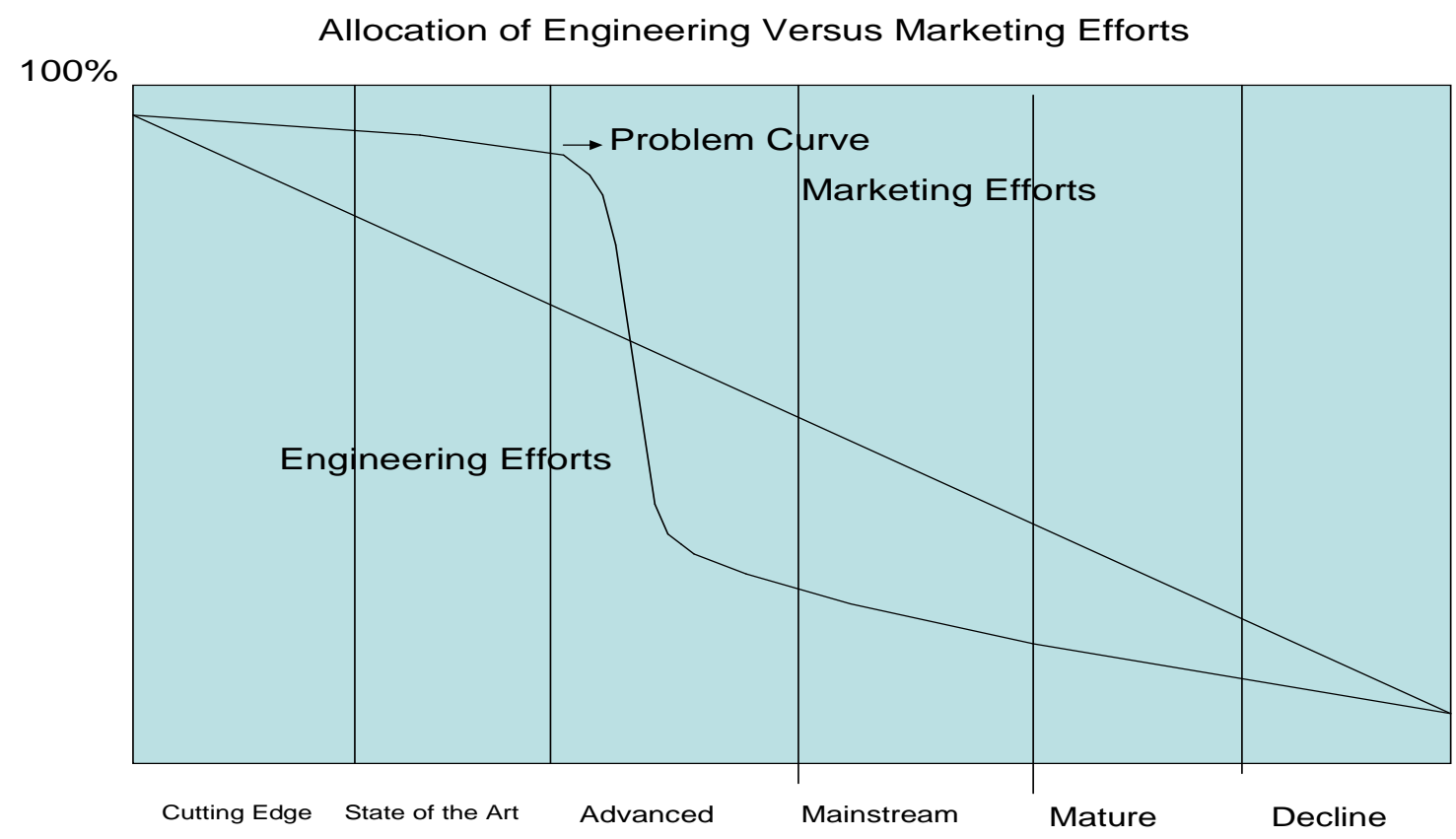

\section{METHODS FOR BALANCING ENGINEERING AND MARKETING ORIENTATION}

Anticipate The Shift From Product To Marketing Orientation, And Build Relationships Between Engineering And Marketing Areas

While this would seem to be the most logical and easiest solution to the problem, it is far from it. Shaw and Shaw (2003) document the difficulties in gaining cooperation between Engineering and Marketing. Attempts to prevent conflict between the areas usually result in premature and ongoing conflict.

\section{Spin Off A "Cutting Edge" Research Affiliate}

Allow your top researcher to form their own firm. Often research will develop a technology that is not consistent with the mission of the company, or is just not consistent with the strategic direction of the firm. In such a situation create a spin off research firm in which the company retains some ownership. If your stock is traded, then the market usually prefers having two stocks, each of which is a "pure play".

\section{Form Separate B2B And Consumer Divisions}

Keep your B2B unit as a State of the Art Company serving other businesses. Create a consumer products division that is its own SBU and profit center. Profits can be allocated between the SBU's as needed at the strategic level.

\section{Separate R\&D From Product Development}

Many firms fail to recognize the difference between R\&D and Product Development. The key here is to allow your R\&D department to be product driven, but make sure that Product Development is Marketing driven. Product Development needs to have a closer association with Customer service than with R\&D. 


\section{Match "High-Tech" Research Efforts With Efforts At "High-Touch" Research}

Integrate "High-Tech" and 'High-Touch" into the mission of your firm. Naisbitt's (1982) predicted that consumers would increasingly refuse any technology that did not empower, or make the consumer "feel" good about its use. Yet, how many firms spend as much on assuring the "high-touch' component of their offerings as they do the technological component of the their offering. Consumers purchase products that make them "feel" better about themselves. Technologies that make consumers "feel" stupid, useless, or inadequate are unlikely to be successful.

\section{BIBLIOGRAPHY}

1. $\quad$ Naisbitt, John Megatrends, Warner Books (1982)

2. Buskirk, Bruce, The Technology Life Cycle and Industrial Market Behavior, Industrial Management and Data Systems, Nov.-Dec. (1986).

3. Buskirk, Bruce, E.T. Popper and Allan C. Reddy Planning Market Development in High-Tech Firms, Technovation, Vol. 14, No. 7, pp. 1-11,(1994).

4. Popper, Ed, and Bruce Buskirk Technology Life Cycle and Industrial Markets Industrial Marketing Management, pp.23-31, February (1992).

5. Eric Craymer, Glenn S. Omura, A Portfolio Approach to Modeling Firm Growth Patterns, presented at the $41^{\text {st }}$ International Small Business Conference World Conference, Stockholm, Sweden 1996

6. Shaw, Viviene, et. al, Conflict between engineers and marketers, Industrial Marketing Management, V.32 \#6 Aug. (2003) 
NOTES 